Svitlana Kolosok,

Ph.D., Associate Professor, Sumy State University, Ukraine

iD ORCID ID, 0000-0002-5133-9878

email:kolosok@management.sumdu.edu.ua

Agnieszka Jakubowska,

Koszalin University of Technology, Poland

(iD) ORCID ID, 0000-0002-3610-8713

email: agnieszka.jakubowska@tu.koszalin.pl

Correspondence author: kolosok@management.sumdu.edu.ua

\title{
COVID-19 AND PUBLIC HEALTH ADMINISTRATION: TRENDS AND PROSPECTS
}

Abstract. This paper provides a bibliographic analysis of the scientific background devoted to public health administration prospects regarding spreading coronavirus disease worldwide. The study sample consists of 1240 scientific documents on public health administration published from 2015 to 2021. The search of relative documents was conducted by the keyphrase «public health administration» in the document titles, abstracts and keywords. The publications' source is the Scopus database. The software VOSviewer version 1.6.15 was used to visualize the network map of keywords co-occurrences under the restriction of at least 40 keyword occurrences in the study sample. The obtained results allowed identifying four clusters indicating the research directions of investigated publications. Therefore, the first cluster is focused on gender and age differences. The author found that these documents were published mostly in 2018. The second cluster indicated the current research direction in investigating public health administrations and COVID-19. The author noted the growing scientists' interest in coronavirus infection issues, virus pneumonia, coronavirus disease 2019, disease outbreaks and COVID-19 since 2020. Moreover, the scientists were interested in studying the planning and control of the coronavirus incidence regarding proper health administration. The third cluster indicated researching health policy, especially health care policy, health care planning, health care delivery, and health equity. In turn, the fourth cluster is the most powerful by keyword links in the study sample. The author noted that the fourth cluster is the most powerful by keyword links. This cluster consists of 28 terms, while the most important terms by link strengths are public health administration, public health service. Besides, it indicates the research direction on procedures, standards, organization, and public health management. The obtained results allowed assuming that further studies would be devoted to healthcare institutions' administration and financial provision, vaccination against COVID-19 and assessing its impact.

Keywords: coronavirus infection, health care planning, health care policy, infections control, public health service.

Introduction. The worldwide spread of coronavirus disease has resulted in radical changes in all spheres of people's life and their behavior. Thus, all kind of activities has transformed. Notably, health care management greatly influences the life and physical conditions of the staff of medical clinics, hospitals, and all public health care systems. At the same time, the administration of health care facilities is also responsible for patient care quality.

Undoubtedly, the COVID-19 pandemic requires new procedures and methods for organizing and managing public health services. For maintaining health on the national level, it is necessary to implement the tools addressing to prevent the dangers of rapid disease growth. Public health care systems need to immediately deploy anti-epidemiological measures to overcome the severe consequences of the disease and massively provide twenty-four-hour and population safety. However, the government's remedial actions against pandemic have been accompanying by critical resistance and unrest of the dissatisfied society. Thus, citizens react strongly against restrictions on rights and freedoms, the economic consequences of lockdown, and restrictions caused by the coronavirus infection risk increase.

Cite as: Kolosok, S., \& Jakubowska, A. (2020). Covid-19 and Public Health Administration: Trends and Prospects. Health Economics and Management Review, 1, 69-75. http://doi.org/10.21272/hem.2020.1-06 
The mentioned above explains the growth of scientists' interest in this topic under the worsen coronavirus infection situation. Accordingly, many exploratory works describing the procedures, policies, and areas of change to overcome viral infections such as COVID-19 have emerged in the field of public health administration.

Literature Review. Nowadays, research on public health administration is of great importance. It stands to mention the publication in the editorial column The Lancet (Lancet, 2020) that emphasized the necessity for changes in the administration system of the healthcare facilities. The magazine's editor called for a more robust reaction of political leaders to the threat of SARS-CoV-2 to assure the better provision of hospitals with resources (equipment, individual protection, medicines) and medical staff (systematic training of hospital staff and approving treatment guidelines for coronavirus disease). Shamasunder et al. (2020) concluded that the total underfunding policy in health care is caused by the dominance of neoliberal privatization in society, ideological aspects and disparities. It seems clear that governments should further increase healthcare funding to be more responsive to epidemiological situations (Chauhan, 2020; Maani and Galea, 2020).

In the study frame (Haffajee and Mello, 2020), the authors noted the slow and uneven US federal government response to the coronavirus's spread. Many US jurisdictions have not implemented the CDC recommendations on social distancing on time. In turn, South Korea and Taiwan's governments had a centralized national strategy to combat the disease. Thus, the American approach to overcome the pandemic yielded was less effective. The experience of Latin America showed that health care systems were underfunded. Besides, policy errors of leaders prevented timely preparations for COVID-19 threats. In turn, African countries responded belatedly to the disease's spread (Massinga Loembe et al., 2020).

In stands to mention that the level of success of epidemic control measures depends on the population behavioural aspects and their awareness of the threat degree. Betsch (2020) discussed the need for massive and rapid changes in social distancing and control behaviour. A while later, the scientists (Betsch et al., 2020) considered the features of wearing masks to keep social distancing. Many scientists emphasized that data analytics and medicine digitalization investments (Betsch, 2020; Smith and Fraser, 2020) are necessary to understand the disease incidence, pandemic characteristics and support public health decision-making (Betsch, 2020; Smith and Fraser, 2020). Furthermore, data analysis provides an understanding of the trends in public health administration.

Methodology and research methods. The first study sample was generated with 1240 publications indexed in the Scopus database to identify the scientific directions and prospects for public health administration research. The search of relative documents was conducted by the keyphrase «public health administration» in the document titles, abstracts and keywords. The publication period was 2015-2021. VOSviewer visualization tools (version 1.6.15) were used to visualize the generated study sample. The network map of keywords co-occurrences was built under the restriction of at least 40 keyword occurrences in the study sample. For better map visualization, the minimum cluster size was 5 items, while small clusters were combined. The method of measuring the strength of the association of items was chosen to normalize terms' values.

The study sample was further concretized by the keyword «covid» in the Scopus database to identify relevant publications on the investigated topic. Therefore, the study sample is 106 documents published in the scientific journals indexed by the Scopus database.

Results. The obtained results of investigated documents visualization on public health administration allowed identifying four clusters (Fig. 1). The first cluster (blue) consists of 24 terms. In turn, the most mentioned term of this cluster has 98 links with other terms (a link strength is 3535 standard unit). This cluster mostly combines publications devoted to studying gender differences between men and women, age differences (between older people, middle-aged and adolescents). Besides, the absolute majority of documents were published in 2018. Analysis of this cluster showed that to collect data for the cross- 
sectoral study, researchers used different methods (controlled study, questionnaire on health, human experiments, interviews, clinic-based studies, statistical studies etc.).

The second cluster (yellow) appeared more recently due to the COVID-19 pandemic. There has been an increase in the number of publications devoted to public health administration under COVID-19 since 2020 (Figure 2). These publications are committed to investigating coronavirus infection, virus pneumonia, coronavirus disease 2019, disease outbreaks, and COVID-19. Besides, researchers were interested in studying the planning and control of the coronavirus incidence under proper health administration. That is confirmed by the phrases in publications such as disaster planning, infection control, prevention and control.

The third cluster (red) is more related to healthcare policy. The total number of cluster terms is 29 . It includes publications devoted to health care policy, health care planning, health care delivery, and health equity. Besides, it is worth mentioning that this cluster includes the concepts of health care cost, financial management, and economics.

The fourth cluster (green) is the most powerful by keyword links. This cluster consists of 28 terms. In turn, the most essential terms by link strengths are «public health administration», «public health service», and «human». Notably, the link strength with the term «public health administration» is the largest (2396 standard unit). Besides, this cluster includes the terms describing procedures, standards, organization, and management in the field of public health.

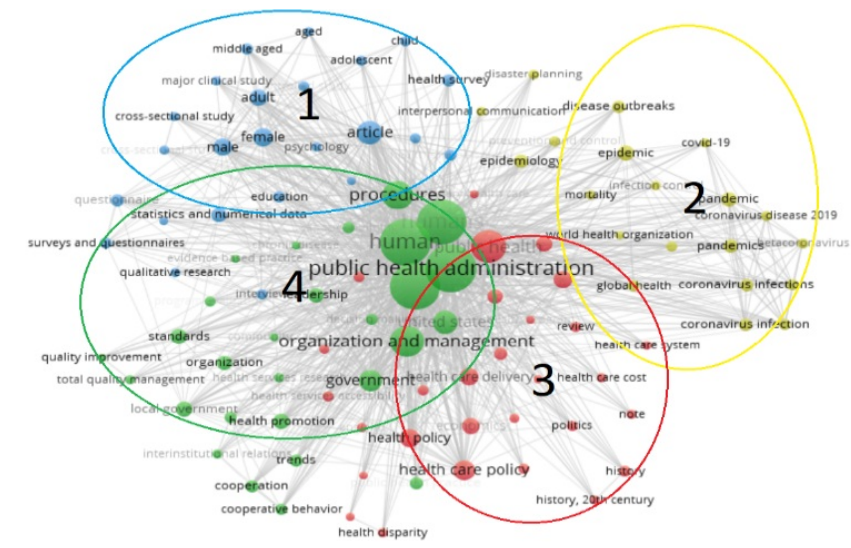

Figure 1. Visualizing research clusters on «public health administration», 2015-2021

Sources: developed by the author based on Scopus.

An in-depth analysis of the second cluster showed the priority subject fields of investigated publications. Therefore, it was found that $62.6 \%$ of publications belong to the subject field of Medicine, $6.5 \%$ - Biochemistry, Genetics and Molecular Biology, 5.0\% - Environmental Science, and 4.3\% - Social Sciences. (Figure 3). Besides, more than three percent of publications were devoted to both Neuroscience and Nursing.

Figure 4 shows that the scientists from developed and developing countries were the most interested in the investigated issue. However, the most active scientists were from the United States $(41.5 \%$ of all publications), while scientists by Harvard university affiliation published 11 documents (Table 1). Herewith, the top-five productive countries were the UK, Australia, Canada and China.

Systematization of scientific background indicated the growing tendency in publication activity on the relationship between COVID-19 and public health administration. The findings showed that despite the novelty and complicacy of the investigated subject, many scientists such as Betsch C., Burkle F., Galea S., Mello M., Nomani M. had published several scientific papers in this field. In turn, the most cited 
scientists were Betsch C. (University of Erfurt, Germany), Galea S. (Boston University School of Public Health, United States), and Mello M. (Stanford University School of Medicine, United States). These authors mostly focus on investigating approaches and procedures implemented by different countries to prevent COVID-19.

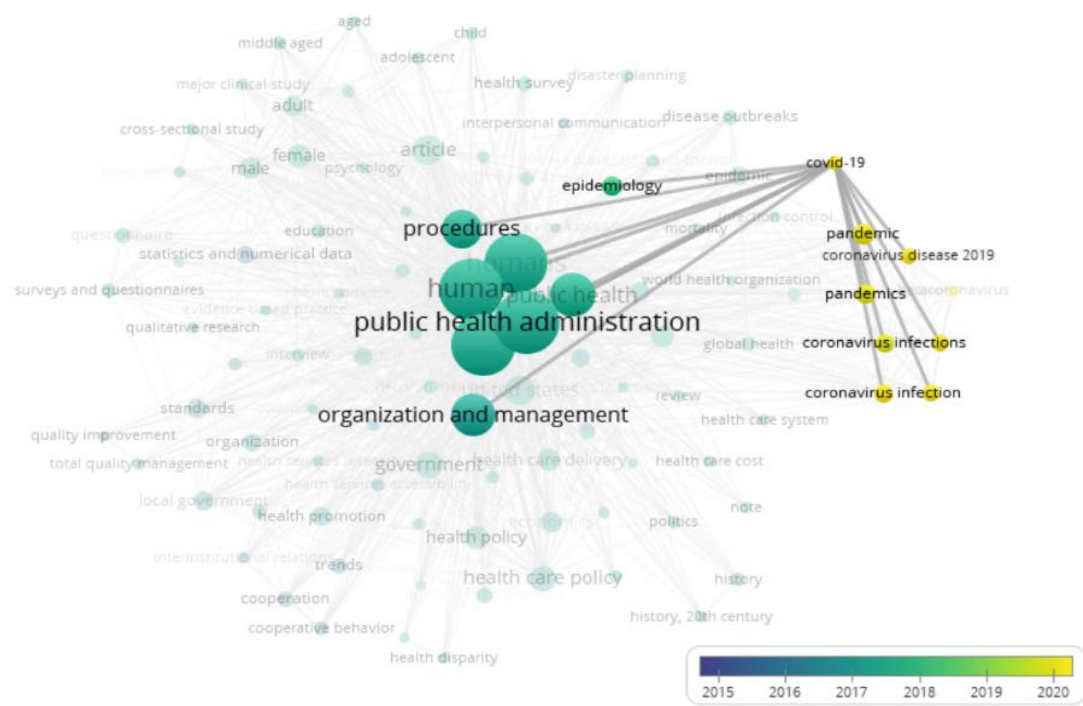

Figure 2. The links of the term «COVID-19», 2015-2021

Sources: developed by the author based on Scopus.

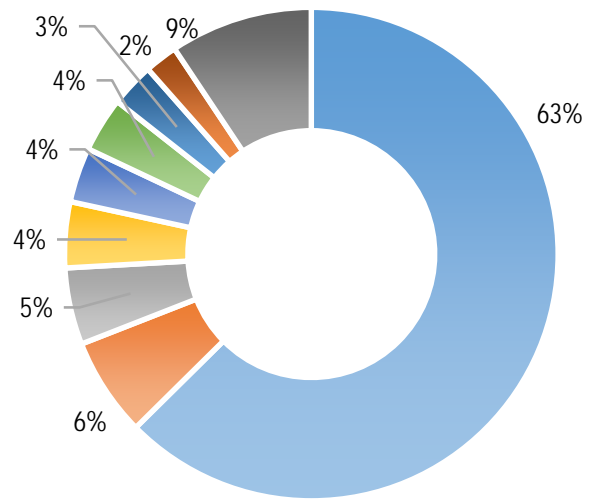

Medicine

- Biochemistry, Genetics and Molecular

Biology

Environmental Science

- Social Sciences

- Neuroscience

- Nursing

Figure 3. Papers by subject area, 2020-2021

Sources: developed by the author based on Scopus.

The obtained results showed that several scientific schools provided the growth of the total number of citations. Notably, the scientists from the USA, UK and Chine cited mostly. It stands to mention the scientists from the London School of Hygiene \& Tropical Medicine cited 18 publications, while the scientists from the University of Toronto -11 publications. 


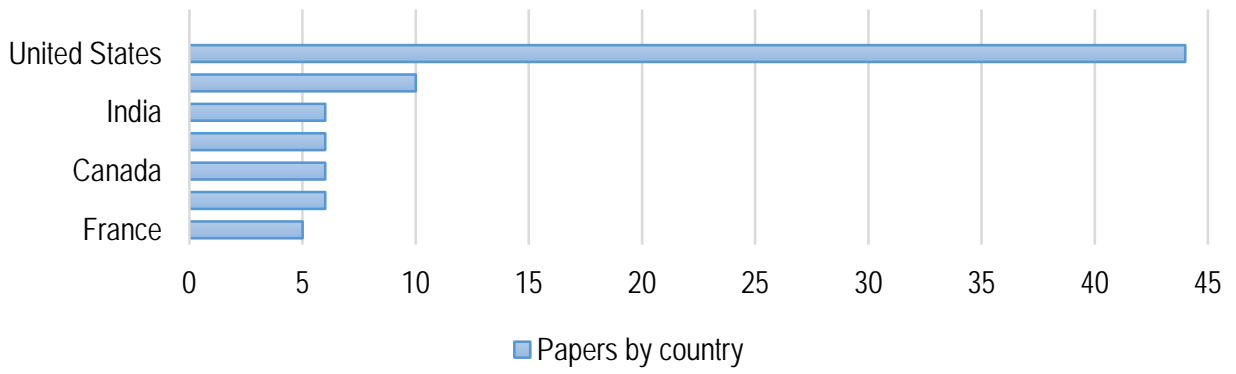

Figure 4. Papers by country, 2020-2021

Sources: developed by the author based on Scopus.

Table 1. Papers by affiliation, 2020-2021

\begin{tabular}{ccc}
\hline Affiliation & Country & Papers' counts \\
\hline Harvard Medical School & United States & 5 \\
Harvard University & United States & 3 \\
University of Toronto & Canada & 3 \\
The University of North Carolina at Chapel Hill & United States & 3 \\
Organisation Mondiale de la Sante & Switzerland & 3 \\
\hline Harvard T.H. Chan School of Public Health & United States & 3 \\
\hline
\end{tabular}

Source: developed by the author based on Scopus.

Table 2. Papers by affiliations, $2020-2021$

\begin{tabular}{|c|c|c|c|c|}
\hline Document title & Authors & $\begin{array}{c}2020 \\
\text { Citations }\end{array}$ & $\begin{array}{c}2021 \\
\text { Citations }\end{array}$ & $\begin{array}{c}\text { Total } \\
\text { Citations }\end{array}$ \\
\hline COVID-19: too little, too late? & The Lancet & 46 & 11 & 57 \\
\hline $\begin{array}{l}\text { Thinking globally, acting locally - } \\
\text { The U.S. Response to Covid-19 }\end{array}$ & Haffajee R.L., Mello M.M. & 45 & 10 & 55 \\
\hline $\begin{array}{l}\text { How behavioural science data helps } \\
\text { mitigate the COVID-19 crisis }\end{array}$ & Betsch C. & 24 & 8 & 32 \\
\hline $\begin{array}{l}\text { Straining the system: Novel } \\
\text { coronavirus (Covid-19) and } \\
\text { preparedness for concomitant } \\
\text { disasters }\end{array}$ & Smith N., Fraser M. & 18 & 7 & 25 \\
\hline $\begin{array}{l}\text { COVID-19 in Africa: the spread and } \\
\text { response }\end{array}$ & $\begin{array}{l}\text { Massinga Loembe M., } \\
\text { Tshangela A., Salyer } \\
\text { S.J., Varma J.K., Ouma } \\
\text { A.E.O., Nkengasong J.N. } \\
\text { Shamasunder S., Holmes }\end{array}$ & 14 & 5 & 19 \\
\hline $\begin{array}{l}\text { COVID-19 reveals weak health } \\
\text { systems by design: Why we must } \\
\text { re-make global health in this } \\
\text { historic moment }\end{array}$ & $\begin{array}{l}\text { S.M., Goronga T., } \\
\text { Carrasco H., Katz E., } \\
\text { Frankfurter R., Keshavjee } \\
\text { S. }\end{array}$ & 15 & 3 & 18 \\
\hline $\begin{array}{l}\text { Comprehensive review of } \\
\text { coronavirus disease } 2019 \text { (COVID- } \\
\text { 19) }\end{array}$ & Chauhan S. & 10 & 4 & 14 \\
\hline
\end{tabular}


Continued Table 2

\begin{tabular}{|c|c|c|c|c|}
\hline $\begin{array}{l}\text { COVID-19 and Underinvestment in } \\
\text { the Public Health Infrastructure of } \\
\text { the United States }\end{array}$ & $\begin{array}{l}\text { Maani N., Galea S. } \\
\text { Litewka S.G., Heitman E. }\end{array}$ & $\begin{array}{l}10 \\
10\end{array}$ & $\begin{array}{l}4 \\
3\end{array}$ & $\begin{array}{l}14 \\
13\end{array}$ \\
\hline $\begin{array}{l}\text { Social and behavioral } \\
\text { consequences of mask policies } \\
\text { during the COVID-19 pandemic }\end{array}$ & $\begin{array}{l}\text { Betsch C., Korn L., } \\
\text { Sprengholz P., } \\
\text { Felgendreff L., Eitze S., } \\
\text { Schmid P., Bohm R. } \\
\end{array}$ & 6 & 6 & 12 \\
\hline
\end{tabular}

Sources: developed by the author based on Scopus.

Conclusions. This study confirmed the relevance of investigating public health care administration in terms of the COVID-19 pandemic. Herewith, obtained results of bibliographic analysis allowed to highlight four clusters of thematic directions of investigated publications. Thus, the first cluster indicated the relevance of studies on gender differences between men and women, age distinctions (between older people, middle-aged and adolescents). The second cluster focused on issues of public health administration and COVID-19 features. This cluster combines the recent publications devoted to coronavirus infection, virus pneumonia, coronavirus disease 2019, disease outbreaks and COVID-19.

Moreover, the scientists were interested in studying the planning and control of the coronavirus incidence under proper health administration. The third cluster devoted to healthcare policy, especially health care planning, health care delivery, and health equity. In turn, the fourth cluster is the most powerful by keyword links. In this cluster, out of 28 terms, the most important terms by link strengths are public health administration, public health service, and human. Besides, this cluster indicates the research direction on procedures, standards, organization, and public health management. The obtained results allowed concluding that further investigations would be devoted to the administration and financial provision of healthcare institutions, vaccination against COVID-19 and assessing its impact.

Author Contributions: conceptualization, methodology, software, validation, formal analysis, investigation, resources, data curation, S. K.; writing-original draft preparation, A. J., S. K.; writing-review and editing, A. J.; visualization, S K.; supervision, project administration, A J.

Funding: This research received no external funding.

\section{References}

Betsch, C. (2020). How behavioural science data helps mitigate the COVID-19 crisis. Nature human behaviour, 4(5), 438-438. [Google Scholar] [CrossRef]

Betsch, C., Korn, L., Sprengholz, P., Felgendreff, L., Eitze, S., Schmid, P., \& Böhm, R. (2020). Social and behavioral consequences of mask policies during the COVID-19 pandemic. Proceedings of the National Academy of Sciences, 117(36), 21851 21853. [Google Scholar] [CrossRef]

Chauhan, S. (2020). Comprehensive review of coronavirus disease 2019 (COVID-19). Biomedical Journal, 43(4), 334-340 [Google Scholar] [CrossRef]

Haffajee, R. L., \& Mello, M. M. (2020). Thinking globally, acting locally-The US response to COVID-19. New England Journal of Medicine, 382(22), 75. [Google Scholar] [CrossRef]

Litewka, S. G., \& Heitman, E. (2020). Latin American healthcare systems in times of pandemic. Developing World Bioethics, 20(2), 69-73. [Google Scholar] [CrossRef

Maani, N., \& Galea, S. (2020). COVID-19 and underinvestment in the public health infrastructure of the United States. The Milbank Quarterly, 98(2), 250-259. [Google Scholar] [CrossRef]

Loembe, M. M., Tshangela, A., Salyer, S. J., Varma, J. K., Ouma, A. E. O., \& Nkengasong, J. N. (2020). COVID-19 in Africa: the spread and response. Nature Medicine, 26(7), 999-1003. [Google Scholar] [CrossRef] 
Shamasunder, S., Holmes, S. M., Goronga, T., Carrasco, H., Katz, E., Frankfurter, R., \& Keshavjee, S. (2020). COVID-19 reveals weak health systems by design: why we must re-make global health in this historic moment. Global Public Health, 15(7), 1083-1089. [Google Scholar] [Crossref]

Smith, N., \& Fraser, M. (2020). Straining the System: Novel Coronavirus (COVID-19) and Preparedness for Concomitant Disasters. American Journal of Public Health, 110(5), 648. [Google Scholar] [CrossRef]

Lancet, T. (2020). COVID-19: too little, too late?. Lancet (London, England), 395(10226), 755. [Google Scholar] [CrossRef]

C.І. Колосок, к.е.н., доцент, Сумський державний університет (Україна);

А. Якубовська, Кошалінський технологічний університет (Польща)

COVID-19 та система охорони здоров'я: тенденції та перспективи

у даній роботі проведено бібліографрічний аналіз наукових публікацій, присвячених питанням системи охорони здоров'я та пандемії COVID-19. Вибірка дослідження складається із 1240 публікації, опублікованих у наукових журналах, які індексуються у базі даних Scopus. Періодом дослідження обрано 2015-2021 роки. Для візуалізації тематичних напрямків дослідження, у роботі було використано інструментарій програмного забезпечення VOSviewer версії 1.6.15. Для побудови мережевої карти сполучуваності термінів, критерієм обмеження є частота появи ключового слова понад 40 раз. 3 а результатами дослідження візуалізовано чотири кластери, які вказують на тематичні напрямки досліджень. Перший кластер присвячений дослідженню гендерних аспектів та розбіжностей між людьми похилого віку, дорослими та підлітками. Встановлено, що до першого кластеру входять публікації, які датуються 2018 роком. При цьому до другого кластеру входять публікації 2020 року, які присвячені особливостям систем охорони здоров'я під час пандемії COVID-19. Найбільш вагомими термінами даного кластерує коронавірусна інфекція, пневмонія, коронавірусна хвороба 2019, спалахи хвороби та COVID-19. До того, особливу увагу приділено особливостям планування та контролю за поширення коронавірусу за ефрективної системи охорони здоров'я. Третій кластер свідчить про дослідження питань політики у сфрері охорони здоров'ям. До даного кластеру входять 28 термінів, які свідчать про тематику досліджень щодо політики у сфрері охорони здоров'ям, планування у сфрері охорони здоров'ям, надання медичної допомоги та забезпечення рівност у ссрери охорони здоров'я. Четвертий кластер є найбільш вагомим за кількістю зв'язків між термінами. Цей кластер складається із 28 термінів, серед яких найвагомішими за силою зв'язку є система охорони здоров'я, медичне обслуговування та людина. До того, до даного кластеру входять дослідження, присвячені процедурам, стандартам, організації та управлінню у сфері охорони здоров'я.

Ключові слова: державна система охорони здоров'я, коронавірусна інфекція, планування в системі охорони здоров'я, політика системи охорони здоров'я, боротьба з інфекціями.

Manuscript received: 15.08 .2020

(c) The author(s) 2020. This article is published with open access at Sumy State University. 